ask himself whether the prescription of such medicaments is really indispensable. We have not used any narcotics for many years and have successfully treated paraplegics with drug addiction. There are 6 alcoholics among the patients in question, but they should not present a percentage much above that of the general population. Only one case of attempted suicide is mentioned in our files-a fact which very clearly points out that the injured have adjusted themselves quite well to their new conditions of life.

In conclusion, one can reasonably say that the German paraplegic miner meets with good conditions in life. He receives a satisfactory income and is given the opportunity, by way of allowances and advances, to obtian a flat or house suited to his needs. All kinds of aids and appliances are put at his disposal and he is also well cared for after the completion of hospital treatment. A paraplegic is very rarely put in a nursing home. Divorces are just as rare.

The results of our attempts to re-integrate the paraplegic miner into our working life are rather depressing. Here, many tasks lie ahead of us. But, as in other fields, we must not relax in constantly trying to improve the social situation of these most severely disabled persons.

\title{
THE PARAPLEgIC PATIENT AS A SOCIAL PROBLEM
}

\author{
By M. Damanski, M.D. \\ Liverpool Regional Paraplegic Centre, Promenade Hospital, Southport, Lancashire
}

THE social significance of a paraplegic patient's disability can be fully understood only if his personal background, age, circumstances of the injury, income and the facilities for domestic resettlement and re-employment are given adequate consideration. This is the purpose of this paper, which is based on the study of 300 paraplegic patients admitted to the Southport Centre over the period of 17 years.

The area covered by this Centre is made up of coal-mining regions, concentrations of heavy and light industry, and agricultural communities, all conected by busy overland communication lines and served by two large ports. It contains $1 a$ cities with their complicated social structure, medium-sized and small towns, and villages. It can, therefore, be assumed that the patients studied represent a trie cross-section of all the social classes and their related physical hazards in this courtry and perhaps those of any other country with a similar economic structure.

Age of Patients. Table I gives an idea of the age of the patients. It is clear that the incidence is highest in the third and fourth decades of life, and these patiencs constitute about half the total number of paraplegic patients.

Circumstances of Spinal Injury. Table II gives an idea of the circumstances of spinal injury. The hazards described as industrial account for about so per cent. of paraplegia. Mainly manual workers, skilled and unskilled, lacking an adequate educational background to enable them to switch over to office work, they live with their large families, often in cld and primitive houses, with inadequate saritation, etc. Although they may have been earning a substantial income, they do rot appear to have acquired the habit of saving for a rainy day. An accidentinsurance policy is rather the exception than the rule. 


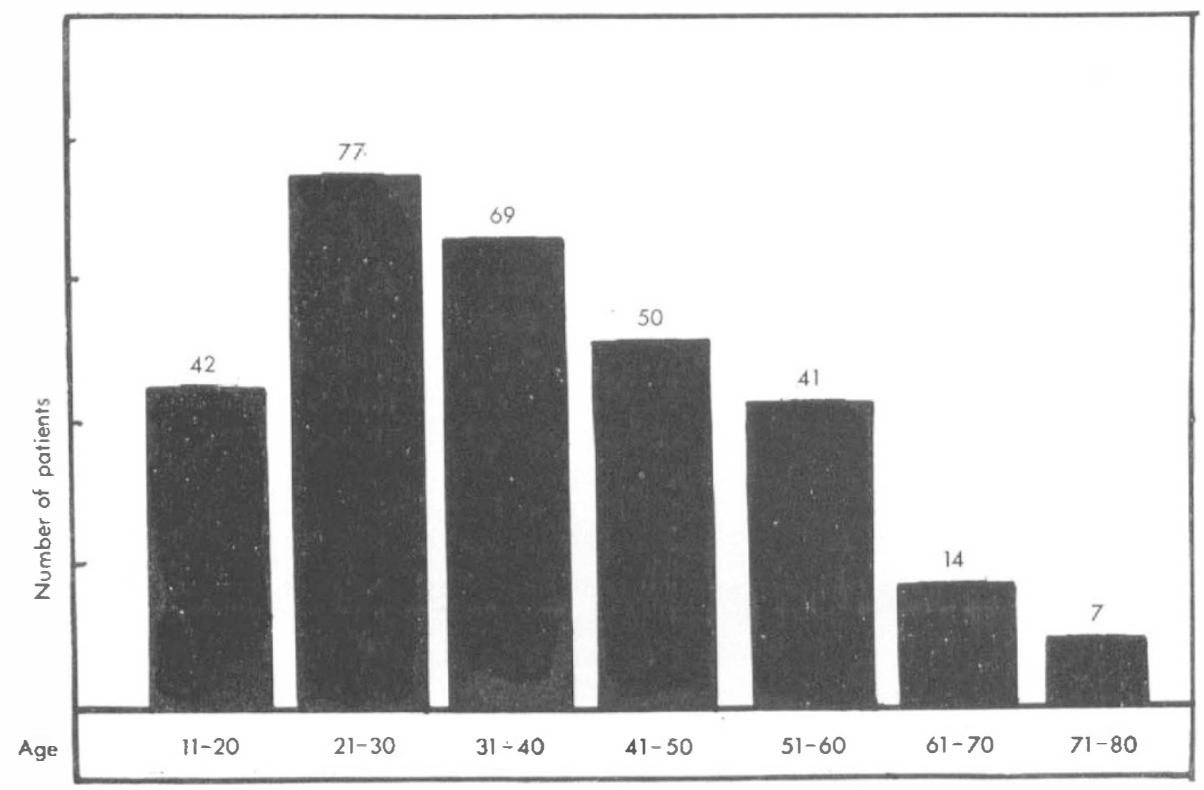

About Io per cent. of the paraplegic population are Service casualties. Officers and other ranks are involved in the same relative numbers as corresponds to the normal structure of the armed forces. Officers with their higher educational standard and higher social ambitions adapt themselves better to the changed circumstances of life. The majority of the other ranks are in a similar position to that of the manual workers.

About 40 per cent. of paraplegic patients are victims of activities which are carried out independently of social background, about half of them being victims of road-traffic accidents. A bicycle or motor-cycle provides little protection in the event of a collision, and as their riders are mainly juveniles, the proportion of young people with an unfinished school education or apprenticeship and with no eligibility for benefits from the National Insurance Schemes is high in this group.

Circumstances of Spinal Injury and Income from the National Insurance Schemes. The statutory benefit for a paraplegic patient who has paid sufficient contributions to the state-contributory schemes at the time of his spinal injury depends on the circumstances of the accident. Some patients are not entitled to any benefit because they were paying no contributions at all (mainly juveniles and housewives), or because they had paid less than the statutory requirement of three years.

The ratio of the employed and non-employed casualties is influenced by age. The figures of incidence according to age appearing in Table I have been further 
TABLE II

Occupational Risks resulting in Traumatic Paraplegia

I. Industrial

Summary:

Building and ancillaries

Mining

Docks and warehouses

Ships and barges

Factories

Road + rail transport .

Agriculture

Window cleaning

Professional sports

2. Armed Forces

3. Other hazards

Summary:

Road traffic

Motor-cycle

Car

Bicycle .

Pedestrians

Domestic .

Sports and games

Attempted suicide

Attempted burglary

$$
\begin{aligned}
& \text {. . . . . . I49 } \\
& \cdot \cdot \cdot \quad \cdot 52 \\
& \text {. } . \quad . \quad . \quad 27 \\
& 20 \\
& \text { I3 } \\
& \text { I } 2 \\
& 9 \\
& 8 \\
& 5 \\
& 3 \\
& 31 \\
& \text { I } 20 \\
& 65 \\
& \text { 2I } \\
& 19 \\
& \text { I3 } \\
& \text { I2 } \\
& \text {. } 30 \\
& \text { I7 } \\
& 5
\end{aligned}
$$

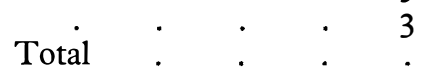

31
120

divided into two classes in Table III. Those who suffered injury whilst earning their living are shown in black columns and those injured whilst pursuing other activities are shown in shaded columns. This analysis shows that of those in the fifth decade of life comparatively few engage voluntarily in the activities which carry an inherent risk of accident, about three-quarters of them suffering their spinal injury whilst earning their living and only one-quarter when doing something unconnected with employment. The ratio changes towards both ends of the age ladder in favour of the non-essential dangerous activities. On the one end are young people between II and 20 , only about 30 per cent. of them being victims of the employment risk and the remaining 70 per cent. suffering their injury as a result of the natural liking for sports, games, pedal or motor cycling. Among those at the older end of the age ladder, however, are numerous victims of road accidents incurred when returning from a public house late at night or of domestic accidents after return home, the typical history being a fall downstairs when visiting a toilet.

In accordance with the provisions of the National Insurance Act, a person who has suffered his or her injury whilst working for an employer is treated as an industrial-injury case and is in a privileged position. Apart from that, if it should be that the employer has neglected some safety precautions, the patient may take the matter to Court and may be awarded a substantial sum in compensation which, if wisely invested, brings in a handsome interest. Other patients though are in a considerably worse financial situation.

Table IV, Column A, sets out the financial benefits for an industrial-injury 
patient and Column B, those for a patient who suffered an injury unconnected with his employment. It is clear that whereas the former draws three basic benefits, the latter enjoys one only. Should a paraplegic patient be an uninsured person of I6 years of age or over, he may qualify for a grant from the National Assistance Board which is intended to cover his essential needs, provided he passes a means test. Column $\mathrm{C}$ gives an idea of the sums of money which may be granted by the National Assistance Board.

\section{TABLE III}

Incidence of traumatic paraplegia according to age group and circumstances of injury
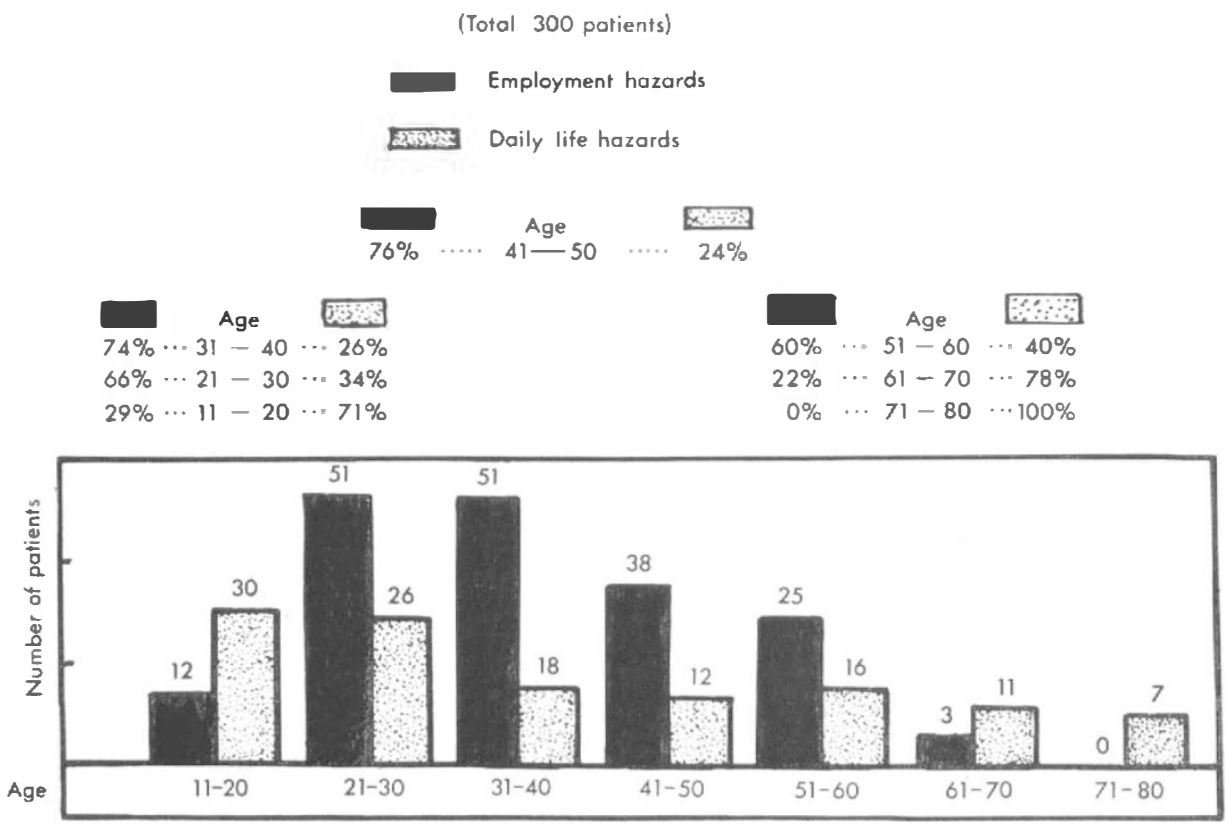

The pension of an ex-serviceman is somewhat more generous than that of an industrial-injury patient.

In the writer's opinion, the levels of the Sickness Benefit and of the grants from the National Assistance Board are far from generous, and these patients often suffer financial hardship. It would be fair to grant them a Constant Attendance Allowance, similar to that which is received by the Industrial Injury cases.

Domestic Resettlement. Most married patients are discharged to their previous homes and are looked after by their wives or husbands. If the house previously occupied does not satisfy the requirements of a paraplegic patient, the local Housing Authority provides a Council House or exchanges the previous one for a more suitable dwelling. Such accommodation is obtained more easily now than in the immediate post-war period when houses were in short supply. Many 
single men also are accepted back to their old homes and are looked after by their parents, brothers or sisters.

There are, however, two classes of patients who present difficult problems.

In the first class are those who suffer either from a cervical lesion (or, in some cases, from a lower lesion, but associated with obesity) which makes them difficult to manage despite uninterrupted care and attention from those who look after them. They often return to the Centre with fresh and large pressure sores and may have to spend more time there than before the first discharge. In the circumstances, it was evidently a wrong decision to discharge them home, as the domestic set-up could not have been expected to work satisfactorily.

\section{TABLE IV}

Weekly Social Benefits of Paraplegic Patients after Discharge from Hospital

\begin{tabular}{|c|c|c|c|c|c|c|}
\hline \multirow{3}{*}{\multicolumn{2}{|c|}{$-\quad \cdots$}} & \multicolumn{4}{|c|}{\begin{tabular}{|c|c|} 
2. Unemployability supplement \\
(or sickness benefit \\
(or grants from N.A.B.)
\end{tabular}} & \multirow{3}{*}{$\begin{array}{l}\text { 3. Constant } \\
\text { attendance } \\
\text { allowance }\end{array}$} \\
\hline & & \multirow{2}{*}{$\begin{array}{l}\text { pension } \\
(100 \% \text { rate })\end{array}$} & \multicolumn{3}{|c|}{$\begin{array}{l}\text { Insured } \\
\text { person }\end{array}$} & \\
\hline & & & $\begin{array}{l}\text { years } \\
\text { or over } \quad \text { Wife }\end{array}$ & $\begin{array}{l}\text { Ist } \\
\text { child }\end{array}$ & $\begin{array}{l}\text { each other } \\
\text { child }\end{array}$ & \\
\hline & $\begin{array}{l}\text { Industrial } \\
\text { injury case }\end{array}$ & $\begin{array}{l}£ 5, \text { iss. od. } \\
\text { (A miner } \\
\text { draws a } \\
\text { supplement } \\
\text { of } £ 2, \text { Is. od. }\end{array}$ & $£ 3,7 \mathrm{~s} .6 \mathrm{~d} . \quad £ 2,7 \mathrm{~s} .6 \mathrm{~d}$. & $£ I$ & I2s. & $\begin{array}{l}£ 2, \text { Ios. od. to } \\
£ 5, \text { os. od. }\end{array}$ \\
\hline & $\begin{array}{l}\text { Sickness- } \\
\text { benefit } \\
\text { case }\end{array}$ & - & $£ 3,7$ s. 6d. $\quad £ 2$, is. 6d. & $£ \mathrm{I}$ & I $2 \mathrm{~s}$. & - \\
\hline C. & $\begin{array}{l}\text { National } \\
\text { Assistance } \\
\text { Board } \\
\text { case }\end{array}$ & - & $\begin{array}{l}£ 3,3 \text { s. } 6 \text { d. } £ 2, \text { Is. od. } \\
\text { (Aggregated needs) } \\
\text { plus grant for } \\
\text { reasonable rent } \\
\text { and other discret- } \\
\text { ional additions }\end{array}$ & - & - & 一 \\
\hline
\end{tabular}

In the second class are those whom nobody wants to take back. These are mainly young and single men whose parents or relatives are either unwilling or unable to look after them owing to old age, ill-health or other commitments. Widowers living on their own belong to the same class. In the existing state of the paraplegia services, the only choice is a chronic hospital, which is the most unsuitable place.

In his previous paper (Damanski, I96I) the writer pointed out that these patients should be accommodated in residential institutions run on similar lines to the paraplegic centre. In view, however, of the fact that it would be impossible to find a competent nursing and medical staff for these institutions, the only possible solution appears to be to extend the existing paraplegic centres by adding wards for these exceptional patients. 
Severely disabled ex-servicemen, or civilians with a service record, are in a better position. In the North there are two residential centres run by the East Lancashire Homes for Disabled Sailors and Soldiers, Wyborne Gate Home, Southport, and Broughton House, Kersal, Salford, Manchester, 7. In these establishments several patients, difficult to resettle elsewhere, have been placed. In the South, there is the Star and Garter Home, Richmond, founded by the British Women's Hospital Committee, and the Chaseley Trust Home, Eastbourne.

Resettlement in institutions where the patient has to work will be discussed later.

Resettlement at Work. This depends on the patient's medical condition, the opportunities for re-training and re-employment offered to him and his attitude to work.

Medical fitness is a pre-requisite of employment. A paraplegic patient who has been discharged with an uncontrolled urinary infection which gives rise to pyrexia at a most inopportune moment, or one with thin scars after pressure sores, with excessive spasticity, chronic pain or psychological abnormality will not find employment; if he does, this will soon terminate with great disappointment to the patient himself and his employer. A tetraplegic patient only rarely preserves enough useful function to be fit for remunerative employment. Table $\mathrm{V}$ gives the relevant figures. Generally speaking, a young man and one with a low and/or incomplete lesion is more likely to find suitable employment than an old or severly disabled one.

The facilities for the retraining of a paraplegic who is unable to follow his former occupation are numerous and efficient.

The Ministry of labour runs Industrial Rehabilitation Units where patients are prepared, during individually planned courses in workshops providing an industrial atmosphere, for re-entry into the employment field. Expert vocational guidance on the most suitable type of job is also given. There are now I7 I.R.U.s, of which that at Egham, Surrey, is fully residential and equipped to accommodate a small number of paraplegics, while the others can offer the same rehabilitation facilities to those living within daily reach.

There are four residential Colleges and Centres, at Durham, Exeter, Leatherhead and Mansfield, run by voluntary organisations sponsored and financially assisted by the Ministry of Labour. For a more detailed review of these the reader is referred to the writer's paper published in 196I (Damanski, I96I).

As to the opportunities of work open to a medically fit paraplegic, employment either open or sheltered, must be offered to him near his home. Sheltered employment is provided by the 90 Remploy Factories situated all over the country, and in many cases one of them will be in the vicinity of his home. A man who has spent all his life in a particular area is most reluctant to change his residence and settle down in another place. This is also impracticable for the simple reason that he cannot be offered tenancy of a council house without residential qualifications of long standing. A married man has also many family and social ties to sever. A single man, in addition, is unable to live in lodgings and, if willing to be transferred to another area, can live only in a residential institution tied to employment. This will be discussed later. In the writer's experience, the best possible solution is to be re-employed by the former employer, in a changed capacity.

After the First and Second World Wars, several residential institutions for disabled ex-servicemen, tied to employment, were set up. In the North, there is 
the Lyme Green Settlement, run by the St. John and British Red Cross Society, where married couples occupy specially designed bungalows and single men live in their own quarters. Here several of our paraplegics have found accommodation, have to work in workshops and earn their living. There is a similar colony at Kytes, Garston, near Watford, but this is out of the question for our patients owing to its distance from our area.

TABLE V

Resettlement at Work

\begin{tabular}{|c|c|c|c|}
\hline \multicolumn{2}{|c|}{$\begin{array}{l}\text { Level of neurological } \\
\text { lesion }\end{array}$} & Tetraplegia & Paraplegia \\
\hline \multicolumn{2}{|c|}{ Admitted } & 107 & I93 \\
\hline \multicolumn{2}{|c|}{ Died before discharge } & 26 & 7 \\
\hline \multicolumn{2}{|c|}{ Discharged } & $8 I$ & I86 \\
\hline \multicolumn{2}{|c|}{ Unfit for work } & $\begin{array}{l}\text { Most unless } \\
\text { very incomplete } \\
\text { lesion. }\end{array}$ & $\begin{array}{l}\text { (39 died after } \\
\text { discharge) } \\
(54)\end{array}$ \\
\hline \multicolumn{2}{|c|}{ Fit for work } & $\begin{array}{l}\text { Depends on } \\
\text { work offered }\end{array}$ & 132 \\
\hline \multicolumn{2}{|c|}{ Working } & 3 & 52 \\
\hline \multicolumn{2}{|c|}{$\begin{array}{l}\text { Percentage of those } \\
\text { fit for work }\end{array}$} & $\begin{array}{l}\text { Impossible to } \\
\text { determine }\end{array}$ & $39 \%$ \\
\hline \multirow{3}{*}{ 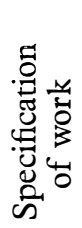 } & Employed & 2 & 35 \\
\hline & Self-employed & - & 13 \\
\hline & $\begin{array}{l}\text { Continued } \\
\text { education }\end{array}$ & I & 4 \\
\hline
\end{tabular}

The Duchess of Gloucester House, Isleworth, originally intended for exservicemen and run by the Ministry of Pensions, and later taken over by the Ministry of Labour, where the patients live and go out to work, does not entirely satisfy our needs owing to its distance from our Centre.

It is the writer's opinion that in view of the general tendency to spread all the facilities evenly over the country instead of concentrating them around London, further accommodation for this type of patient should be available in the NorthWest of England.

As to the paraplegic patient's keeness for work, he is no different to his fellowmen and shares with them human frailty. A patient suffering no financial hardship 
is not as keen to take on work as one who must work for lack of an adequate income. An industrial-injury patient in particular has little financial incentive to work, as he would forfeit his unemployability supplement and the family allowances which go with it, all of them free from income tax. His income from employment would not compensate him appreciably for the loss of social benefits. Besides, if he raises a compensation claim, litigation will be lengthy and during that time he is likely to refuse work so as to give the general impression that his disablement prevents him from doing so. When visited by a representative from the Ministry of Labour (Disablement Resettlement Officer) he will offer many specious excuses for being unable to work, such as pain, spasms, etc. By the time his claim is settled, he has usually lost his habit of work and no longer has any financial interest in it.

Table VI gives the figures of employability and re-employment.

Ex-service paraplegics are employed to a greater extent, about half of them doing remunerative work, possibly owing to their youth and the more sympathetic attitude of everybody concerned.

\section{TABLE VI}

Summary of Working Paraplegic Patients according to the Social Benefits Drawn

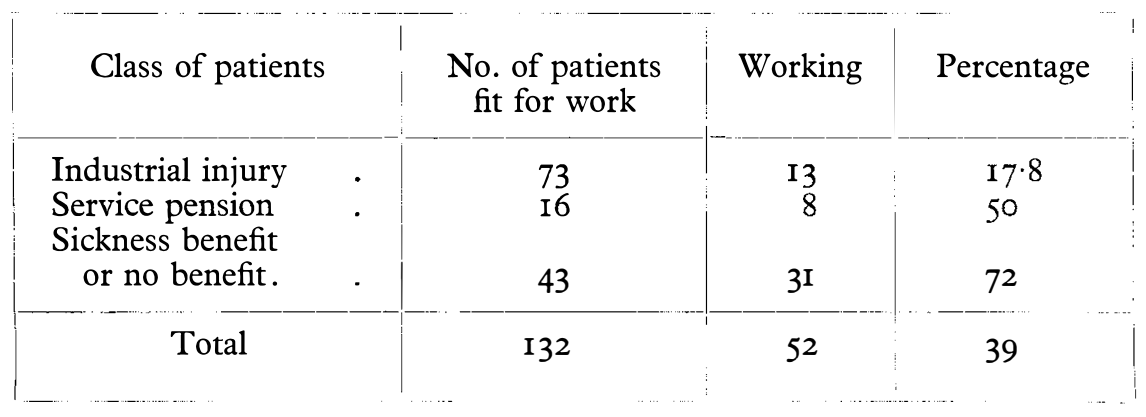

Sickness benefit or no-benefit patients, especially those with a better educational background have a much better record of employment, some of them being self-employed or continuing their education.

Although our record of re-employment may not appear too impressive, the writer does not think that it is really bad. After deduction of about one-third of the tetraplegic patients, we are left with a much smaller number of those who could be considered for employment. Some of the latter did not receive entirely faultless treatment, either in general hospitals or in paraplegic units in the initial stage, and have been rendered unemployable by virtue of their complications. The position in that respect has changed considerably in the last few years and nowadays almost all the paraplegic patients discharged are medically speaking fit for employment.

In conclusion, the writer wishes to point out that for a paraplegic patient to overcome the handicaps of his disability and take up work demands great determination. Not all are endowed with the necessary drive and ambition. Generally speaking, since paraplegic patients are a cross-section of society, like most of us, they work through necessity and few only for pleasure. 


\section{SUMMARY}

I. The incidence of traumatic paraplegia is highest in the third and fourth decades of life.

2. Spinal injury is a result either of an activity undertaken in connection with employment, or some other activity.

3. Most paraplegic patients have to rely on benefits from the M.O.P. \& N.I. Those who meet with their injury whilst working for an employer are classified as industrial-injury cases and draw higher benefits than those who become paraplegic from other causes. The social benefits of the latter group of patients are not satisfactory and ought to be improved by granting them a constant-attendance allowance, similar to that paid to the industrial-injury patients.

4. Patients who do not qualify for benefits from the M.O.P. \& N.I. are sometimes granted money from the National Assistance Board.

5. Service pensions are similar, but somewhat higher than those granted to industrial-injury patients.

6. Industrial-injury patients often obtain compensation from their former employers and become financially independent.

7. Although domestic resettlement is comparatively easy in the case of a married man, if he is severely disabled by the high level of the lesion, or by obesity, it may be difficult. Single men and widows are often most difficult to resettle. It is essential, therefore, that some kind of hospital-type accommodation should be available for them.

8. Ex-service paraplegics, married or single, can be accommodated in special residential centres, accommodation being tied to employment.

9. Resettlement at work depends on the patient's medical fitness, facilities for re-training and re-employment, and his personal attitude to work.

I0. The overwhelming majority of tetraplegic patients are unemployable. Some paraplegic patients are unfit for regular employment owing to physical and psychological complications.

II. There are several facilities for re-training the paraplegic patient in a suitable occupation.

I2. Work must be offered to a paraplegic patient near his home; he is reluctant to accept work in areas other than his own.

I3. There are residential centres for single men, mainly around London, where they work either inside the centre or near it.

I4. A financially independent patient, like one who draws industrial-injury benefit, often supplemented by income from an investment, is more difficult to resettle at work than one who draws sickness benefit or no benefit at all.

I5. The number of employed patients in this series is modest, mainly owing to the high proportion of tetraplegic patients and those with paraplegia who suffered from complications in the early stage. In the last decade the number of medically unfit paraplegics is on the decrease.

\section{REFERENCE}

Damanski, M. (1961). Med. Press, 245, I23. Reprinted in Rehabilitation, 38, 2 I. 